\title{
Effects of forage-to-concentrate ratio and dietary fiber manipulation on gas emissions and olfactometry from manure of Holstein heifers
}

\author{
G. J. Lascano, ${ }^{*}$ A. J. Heinrichs,$\dagger^{1}$ R. R. Gary, $\ddagger$ P. A. Topper,§ R. C. Brandt, $\S$ A. Adviento-Borbe,§ \\ and E. E. Fabian§ \\ *Department of Animal and Veterinary Sciences, Clemson University, Clemson, SC 29634 \\ †Department of Animal Science, The Pennsylvania State University, University Park 16802 \\ fDepartment of Dairy Science, The California Polytechnic State University, San Luis Obispo 93407 \\ §Department of Agricultural and Biological Engineering, The Pennsylvania State University, University Park 16802
}

\begin{abstract}
The objective of this experiment was to determine the effects of differing ratios of forage to concentrate (F:C) and fiber levels on odor and gas emissions from manure. Eight Holstein dairy heifers $(362.45 \pm 4.53 \mathrm{~d}$ of age and $335.6 \pm 7.41 \mathrm{~kg}$ of body weight) were randomly assigned to a split-plot, $4 \times 4$ Latin square design (21-d periods) with $\mathrm{F}: \mathrm{C}$ as the whole plot (20 or $80 \%$ forage) and fiber level as sub-plot $(0,20,40$, or $60 \%$ inclusion of corn stover). Gas concentration was determined using an infrared photoacoustic analyzer over a $24-\mathrm{h}$ period using a steady-state flux chamber setup. Odorous air samples were collected from chamber headspace and evaluated by 6 human assessors using a forcedchoice dynamic olfactometry technique. Emissions of $\mathrm{CO}_{2}$ were greater for the low than high concentrate diets, and no differences were observed for $\mathrm{NH}_{3}$ and $\mathrm{CH}_{4}$ emissions between $\mathrm{F}$ :C. Although F:C had no effect on $\mathrm{NH}_{3}$ emissions, as dietary fiber increased, a linear interaction with opposite effects was found for high and low concentrate diets. Nitrous oxide emissions were below minimum detectable levels. Neither F:C nor neutral detergent fiber level affected odor intensity. Odor emissions were successfully assessed, and manipulation of dietary fiber has the potential to influence $\mathrm{CH}_{4}$ and $\mathrm{NH}_{3}$ emissions.
\end{abstract}

Key words: greenhouse gas emissions, olfactometry, forage to concentrate ratio, dietary fiber, heifer

\section{INTRODUCTION}

National and global environmental policies and regulations are affecting production and operation management strategies on dairy production facilities. An example of these policies is the Clean Air Act regulated by the US Environmental Protection Agency

Received July 17, 2014.

Accepted November 28, 2014.

${ }^{1}$ Corresponding author: ajh@psu.edu that established national ambient air quality standards (Place and Mitloehner, 2010). Dairy operations are associated with the emission of odor, particulate matter, and greenhouse gases (GHG; Laor et al., 2008; Brandt et al., 2011). Although dietary manipulation has been proven to affect GHG and $\mathrm{NH}_{3}$ emissions from the composition of cattle manure (James et al., 1999; Boadi et al., 2004; Misselbrook et al., 2005), actual emission contributions and air quality assessments of dairy heifers fed modern diets are not currently available in the literature.

In dairy cattle manure, $\mathrm{NH}_{3}$ is emitted rapidly once feces are mixed with urine. Ammonia is released from manure as a result of microbiological hydrolysis of urea and uric acid by urease to form ammonium $\left(\mathrm{NH}_{4}{ }^{+}\right)$and its subsequent volatilization to $\mathrm{NH}_{3}$ (Bouwman et al., 1997). Dairy cattle produce around $32 \%$ of the total GHG emitted by livestock in the United States and manure management is an important source of GHG (Leytem and Dungan, 2014). Methane $\left(\mathrm{CH}_{4}\right)$, nitrous oxide $\left(\mathrm{N}_{2} \mathrm{O}\right)$, and carbon dioxide $\left(\mathrm{CO}_{2}\right)$ emitted from cattle operations (US EPA, 2014) from the barn floor (short-term release) or manure storage facilities (longterm release) are influenced by manure composition and other environmental and infrastructural factors (Weiss et al., 2009). Carbon dioxide is emitted into the environment by heterotrophic respiration during degradation of undigested carbohydrates, feed protein, microbial protein, and endogenous protein excreted in feces (Tamminga, 1992). Nitrifying and denitrifying microorganisms in manure are responsible for $\mathrm{N}_{2} \mathrm{O}$ generation and are often enhanced by high levels of labile N (Mosier et al., 1998). Dietary manipulation and nutrient utilization can affect nutrient concentration in manure (Sun et al., 2008a). It has been observed that as dietary fiber increases, DM and OM digestibility are reduced in dairy heifers (Lascano and Heinrichs, 2011), leaving more nutrients to be decomposed, and potentially generating more gases and odors. Under most milking commercial operations, fresh manure is managed such that flushing or scrapping of manure oc- 
curs on average 3 times per day (Sun et al., 2008b), and although most of the methane is generated from enteric fermentation, microbial decomposition of fecal OM during this period has been reported to generate GHG (Lee et al., 2012) and odor that affect air quality in the surrounding areas. The main compounds contributing to nuisance odors are related to carbohydrate and $\mathrm{N}$ decomposition in manure (Miller and Varel, 2001; Le et al., 2005). These compounds are mainly $\mathrm{NH}_{3}$, amines, $\mathrm{CH}_{4}$ (although odorless, it indicates anaerobic conditions, which are responsible for malodorous gas emissions), and volatile organic compounds (VOC) including VFA, sulfur-containing compounds, ketones, phenols, and esters, among others (Laor et al., 2008).

This information above suggests that the amount and type of ingredients ingested by dairy heifers influence nutrient excretion in manure, resulting in differential responses in gas and odor emissions. Therefore, our hypothesis was that increasing fiber content by adding corn stover (CST) to diets with 2 forage to concentrate ratios $(\mathbf{F}: \mathbf{C})$ would increase gas and odor emissions from dairy heifer fresh manure.

\section{MATERIALS AND METHODS}

\section{Animals and Experimental Design}

All procedures involving animals were approved by the Pennsylvania State University Institutional Animal Care and Use Committee (no. 35136). This experiment was conducted parallel to a nutrient utilization study (Lascano and Heinrichs, 2011). In brief, 8 Holstein heifers $(362.45 \pm 4.53 \mathrm{~d}$ of age and $335.6 \pm 7.41 \mathrm{~kg}$ of $\mathrm{BW})$ were randomly assigned to 2 forage levels: high concentrate (HC; $20 \%$ forage) and low concentrate (LC; $80 \%$ forage) and to a forage type sequence $(0$, 20,40 , or $60 \%$ of forage as CST, remainder as corn silage, CS) within forage level administered according to a split-plot, $4 \times 4$ Latin square design with 21 -d periods (Zanton and Heinrichs, 2009). The whole plot factor was diet F:C and the subplot was proportion of CST in the forage fraction of the diet. All diets were provided as TMR at levels calculated to provide similar intakes of ME and to allow for $800 \mathrm{~g} / \mathrm{d}$ of ADG. Intake of $\mathrm{CP}$, minerals, and vitamins was constant across all diets, but NDF and NFC varied with the ingredients composing the treatment rations (Table 1). The concentrate components of the diet were chosen to enable target levels of NDF intakes to be reached and held constant within $\mathrm{F}$ :C to reduce the effect that variation in forage concentration would have on digestion kinetics and fecal output and composition. Heifer BW were measured and averaged on $\mathrm{d} 0$ and 1 and on $\mathrm{d} 7$ and 8 of each period to determine amount of feed offered for the following interval. Rations were mixed daily before feeding at $1200 \mathrm{~h}$ by preparing $\mathrm{HC}$ and LC with 2 different CST to CS ratios (CST:CS) and subsequently mixing proportions of these diets to obtain the other 2 CST:CS. Heifers were housed in individual stalls (117 $\times 302 \mathrm{~cm}$ ) in a ventilated, environmentally controlled tie-stall barn with rubber mattress bedding and were allowed access to an exercise lot for $2 \mathrm{~h}$ before feeding on days on which sampling was not occurring. Water was available ad libitum, and daily consumption was monitored individually using unidirectional flow meters (Sensus Metering Systems, Uniontown, PA).

\section{Sample Collection and Analysis}

Heifers were kept for $30 \mathrm{~d}$ (pretrial period) before starting the experiment to adapt to the tie stall facility and standard herd diets similar to LC no CST diets in this experiment and this treatment was included as previous treatment in the statistical model. Adaptation to treatment rations was made over the first $15 \mathrm{~d}$ of each period; feces and urine were collected from d 15 to 16 (independently from the 6 -d total collection parallel study). Urine was collected via modified urine device (Lascano et al., 2010), weighed, and sub-sampled daily after feeding. Feces were collected hourly and stored in airtight containers; every $24 \mathrm{~h}$ total collection of feces was mixed, weighed, recorded, and sub-sampled. During d 15 and 16 (2 d/period), feces and unacidified, chilled $\left(4^{\circ} \mathrm{C}\right)$ urine were subsampled (1 observation/heifer per period) and analyzed using a bench-top, steady-state (dynamic) flux chamber under laboratory conditions as detailed by Lascano et al. (2008) for gaseous emissions $\left(\mathrm{NH}_{3}, \mathrm{CO}_{2}, \mathrm{CH}_{4}\right.$, and $\left.\mathrm{N}_{2} \mathrm{O}\right)$. Total feces and urine excretion from the first $2 \mathrm{~d}$ of each period were used to determine urine to feces ratio ( $\mathbf{U}: \mathbf{F}$; wet basis) for each heifer. Each individual U:F ratio was used to distribute $200 \mathrm{~g}$ of manure sample for use in the steady-state flux chamber setup (Lascano et al., 2008).

\section{Nutrient Analysis of Diets}

Feedstuffs and TMR were composited by period. Samples were dried in a $65^{\circ} \mathrm{C}$, forced-air oven for 4 $\mathrm{d}$, ground through a 1-mm screen using a Wiley Mill (Arthur H. Thomas, Philadelphia, PA), and analyzed for DM, OM, ash (AOAC, 1990), ADF, sulfuric acid detergent fiber (ADL), and NDF using an Ankom ${ }^{200}$ Fiber Analyzer (Ankom Technology Corporation, Fairport, NY) with heat treated $\alpha$-amylase and sodium sulfite used in the NDF procedure. Starch was analyzed on reground samples $(<0.5-\mathrm{mm}$ screen) using a modified procedure reported by Zanton and Heinrichs (2009). Dried feed and fecal samples, and thawed urine samples 
Table 1. Feed intake of dairy heifers fed differing forage to concentrate ratios (F:C) as low (LC) or high (HC) concentrate diets containing 4 levels of corn stover (CST) addition (0,20,40, or $60 \%$ CST in the 20 or $80 \%$ forage fraction of the diet)

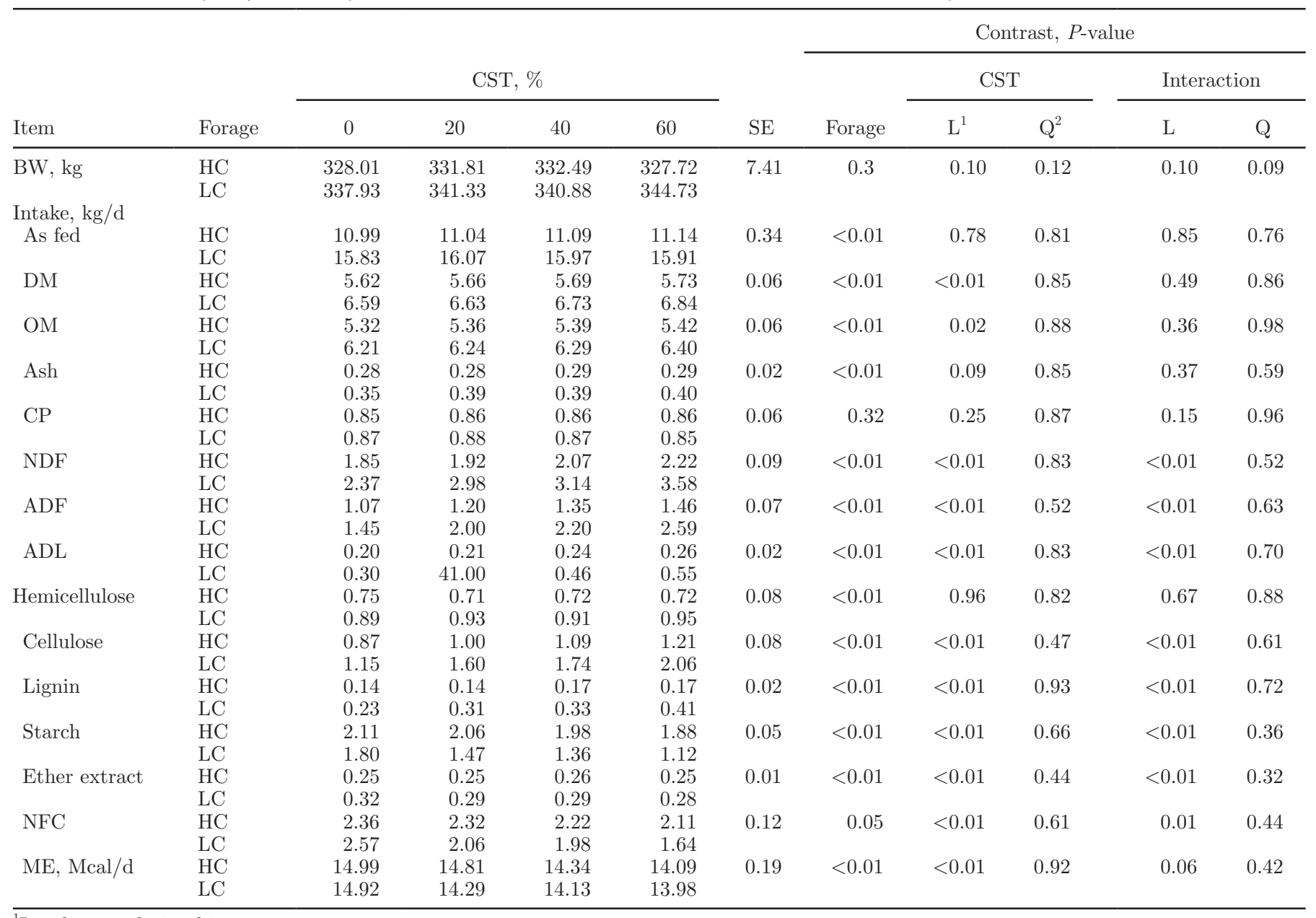

${ }^{1} \mathrm{~L}=$ linear relationship.

${ }^{2} \mathrm{Q}=$ quadratic relationship.

were analyzed for $\mathrm{N}$ using the Kjeldahl method (AOAC, 1990). Metabolizable energy intake was calculated for each heifer within each period using observed digestible OM intake $\times 4.409 \times 0.82(\mathrm{NRC}, 2001)$. Composited TMR samples representing 24 samples/treatment taken daily throughout the collection periods of the experiment were analyzed by Cumberland Valley Analytical Services Inc. (Hagerstown, MD) to determine ether extract and mineral concentrations.

\section{Ammonia and GHG Measurements and Calculations}

Gaseous emissions were quantified using the multichamber, steady-state gas emission detection system under temperature-controlled conditions (Wheeler et al., 2011). In brief, the flux chamber setup used a photoacoustic, multi-gas field-monitor (model 1412, Innova, Ballerup, Denmark) to measure gas concentra- tions from each of 6 flux chambers every 20 min over a 24-h period. Data from samples of the 8 different heifers were collected in 2 separate 24 -h periods ( 5 heifers/24$\mathrm{h}$ period). A repetition of a random fifth heifer was used as an emission control each 24-h period. Five jars each contained $200 \mathrm{~g}$ of manure slurry (feces and urine) combined at the initiation of the gas emission test representing the U:F as excreted by each heifer. The sixth jar contained distilled water as a control, a check for cross-contamination of sampling lines, and for determining background gas concentration levels. Flux chambers were immersed in a $25^{\circ} \mathrm{C}$ water bath Each flux chamber consisted of a 3.8-L glass jar with a continuous supply of $2 \mathrm{~L} / \mathrm{min}$ filtered sweep air. Gas emission rates were computed using the following equation for the steady-state flux chamber setup:

$$
E=\left[Q\left(C_{1}-C_{\mathrm{BLK}}\right)\right] / A,
$$


where $E$ is the gas emission rate of $\mathrm{NH}_{3}, \mathrm{CO}_{2}, \mathrm{CH}_{4}$, or $\mathrm{N}_{2} \mathrm{O}\left(\mathrm{mg} / \mathrm{cm}^{2}\right.$ per $\left.\mathrm{min}\right) ; Q$ is the flow rate of filtered air supplied through each chamber $\left(0.002 \mathrm{~m}^{3} / \mathrm{min}\right)$; $C_{1}$ is the measured gas concentration $\left(\mathrm{mg} / \mathrm{m}^{3}\right) ; C_{\mathrm{BLK}}$ is the measured ambient gas concentration (distilled water chamber in $\mathrm{mg} / \mathrm{m}^{3}$ ); and $A$ is the surface area of manure in each chamber $\left(\mathrm{cm}^{2}\right)$. The daily gas emission $\left(\mathrm{mg} / \mathrm{cm}^{2}\right.$ per d) was computed as the sum of emission rates for $24 \mathrm{~h}$.

\section{Odor Measurements and Calculations}

Within the first hour of manure placement in the multi-chamber, steady-state gas emission detection system, approximately 7.0 L of odorous exhaust sweep air was collected from each of the chambers into a 10-L preconditioned Tedlar bag (Smith Air Sample Supply Co., Hillsborough, NC) for olfactory evaluations. All odor samples were presented to 6 trained panelists and analyzed for detection threshold and recognition threshold levels using an Ac'Scent International Olfactometer (2007; St. Croix Sensory Inc., Stillwater, MN), following the triangular forced-choice method (CEN, 2003).

After use in the olfactometer, the bag containing the odorous gas sample was moved to a different laboratory where each panelist smelled the undiluted bag contents and evaluated each for hedonic tone and intensity. Hedonic tone (pleasantness) was subjectively quantified using a 22-unit scale ( -11 for extremely unpleasant to +11 for extremely pleasant). Panelists assessed odor intensity using the labeled magnitude scale method (nonlinear scale ranging from 0 to 100; Green et al., 1996). All odor panel evaluations were performed within $7 \mathrm{~h}$ of air sample collection, well within the $36-\mathrm{h}$ requirement specified according to international standards (CEN, 2003). Odor emission was computed using equation 1 and odor units $(\mathbf{O U})$, where variable $E$ is odor emission rate of manure $\left(\mathrm{OU} / \mathrm{m}^{2}\right.$ per $\left.\mathrm{s}\right), C_{1}$ is the odor concentration of manure $\left(\mathrm{OU} / \mathrm{m}^{3}\right), C_{\mathrm{BLK}}$ is the odor concentration of preconditioned, $\mathrm{N}_{2}$-filled Tedlar bag $\left(\mathrm{OU} / \mathrm{m}^{3}\right), Q$ is the gas flow rate of the steady-state chamber $\left(3.3 \times 10^{-5} \mathrm{~m}^{3} / \mathrm{s}\right)$, and $A$ is the area of manure surface in each chamber $\left(\mathrm{m}^{2}\right)$.

\section{Statistical Analysis}

Statistical analyses were conducted in SAS version 9.2 for Windows (SAS Institute Inc., Cary, NC) using the MIXED procedure. All dependent variables were analyzed as a split-plot, Latin square design with fixed effects of period, effect of period, and fixed treatment effects of forage level, CS:CST, and their interaction with heifer within forage level included as a random effect. The sequences of CS:CST were balanced for carryover with respect to previous CS:CST levels such that all treatments followed every other treatment once; therefore, fixed effect of previous treatment also was included in the statistical analysis. Forage level effect was assessed with denominator degrees of freedom and error term as associated with whole plot error of heifer within forage, and the effects of CS:CST and the interaction were evaluated against the pooled residual error. Normality of residuals was evaluated using the Shapiro-Wilk test for normality. Differential responses between F:C and CST addition were assessed for some variables through mixed model regression analysis; output from this analysis is displayed as the adjusted (for random effect of heifer) response against CST addition. Least squares means are presented in tables; evidence for statistical significance was declared at $P<0.05$, and trends were indicated at $P<0.10$. Pearson and Spearman correlation coefficients and $P$-values of gas and odor emissions were computed. Data for gas emission versus odor emission were fitted to a mixed model regression analysis when the correlation was found to be significant; output from this analysis is displayed as the adjusted (for random effect of heifer) odor emissions against gas emissions addition. Relationships among average odor intensity and pleasantness scales to gas and odor emission rates were determined using Pearson and Spearman correlation analysis.

\section{RESULTS AND DISCUSSION}

\section{Nutrient Intake and Manure Composition}

Feed intake during the $2 \mathrm{~d}$ collection period for this experiment is presented in Table 1. Diet and chemical composition were the same as the diets offered during the companion parallel study (Lascano and Heinrichs, 2011). Diets were planned to differ mainly in provision of forage fiber, and NDF and ADF concentrations increased linearly in the diet with CST addition. Thus, NDF ranged from 32.85 to $38.02 \%$ in $\mathrm{HC}$ and 35.90 to $52.26 \%$ in LC diets with their respective increases in DM and NDF intakes (Table 1). This resulted in reduced starch and NFC intake to attain isonitrogenous and isocaloric conditions. Intake of $\mathrm{N}$ was similar among treatments $\left(1.69 \mathrm{~g} / \mathrm{kg}\right.$ of $\left.\mathrm{BW}^{0.75}\right)$; this value was reported by Zanton and Heinrichs (2009) to optimize $\mathrm{N}$ utilization in precision-fed heifers. Fecal and urine from heifers fed HC and LC diets with increasing CST proportions are shown in Table 2. Fecal DM content was $3 \%$ higher in manure from HC-fed heifers, showing the water-holding capacity of diets rich in dietary fiber (Lascano and Heinrichs, 2011). Fecal concentration of NDF and ADF was consistently higher for LC manure 
Table 2. Fecal chemical composition of dairy heifers fed differing forage to concentrate ratios (F:C) as low (LC) or high (HC) concentrate diets containing 4 levels of corn stover (CST) addition (0, 20, 40, or 60\% CST in the 20 or $80 \%$ forage fraction of the diet)

\begin{tabular}{|c|c|c|c|c|c|}
\hline \multirow[b]{2}{*}{ Item } & \multirow[b]{2}{*}{ Forage } & \multicolumn{4}{|c|}{ CST, $\%$} \\
\hline & & 0 & 20 & 40 & 60 \\
\hline \multicolumn{6}{|l|}{ Chemical composition } \\
\hline \multirow[t]{2}{*}{$\mathrm{DM}, \%$} & $\mathrm{HC}$ & 19.71 & 19.35 & 20.13 & 20.87 \\
\hline & $\mathrm{LC}$ & 16.04 & 14.46 & 16.11 & 16.31 \\
\hline \multirow[t]{2}{*}{$\mathrm{OM}, \%$ of DM } & $\mathrm{HC}$ & 89.38 & 88.97 & 88.89 & 88.90 \\
\hline & $\mathrm{LC}$ & 89.50 & 90.15 & 89.09 & 88.93 \\
\hline \multirow[t]{2}{*}{$\mathrm{NDF}, \%$ of $\mathrm{DM}$} & $\mathrm{HC}$ & 45.07 & 51.47 & 58.64 & 59.06 \\
\hline & $\mathrm{LC}$ & 65.19 & 64.53 & 68.60 & 65.61 \\
\hline \multirow[t]{2}{*}{$\mathrm{ADF}, \%$ of $\mathrm{DM}$} & $\mathrm{HC}$ & 29.79 & 39.71 & 45.68 & 46.78 \\
\hline & $\mathrm{LC}$ & 51.38 & 48.78 & 56.74 & 52.57 \\
\hline \multirow[t]{2}{*}{ Cellulose, ${ }^{1} \%$ of DM } & $\mathrm{HC}$ & 8.40 & 12.50 & 12.68 & 16.37 \\
\hline & LC & 14.92 & 18.13 & 20.17 & 21.34 \\
\hline \multirow[t]{2}{*}{ Hemicellulose, ${ }^{2} \%$ of DM } & $\mathrm{HC}$ & 16.04 & 11.76 & 12.96 & 13.21 \\
\hline & $\mathrm{LC}$ & 13.26 & 15.76 & 11.35 & 13.04 \\
\hline \multirow[t]{2}{*}{ Starch, \% of DM } & $\mathrm{HC}$ & 4.58 & 4.34 & 4.01 & 5.85 \\
\hline & $\mathrm{LC}$ & 2.68 & 5.34 & 4.23 & 4.74 \\
\hline \multirow{2}{*}{ Ash, $\%$ of DM } & $\mathrm{HC}$ & 6.11 & 6.15 & 6.18 & 7.02 \\
\hline & $\mathrm{LC}$ & 6.63 & 6.18 & 6.60 & 7.28 \\
\hline \multirow[t]{2}{*}{$\mathrm{CP}, \%$ of $\mathrm{DM}$} & $\mathrm{HC}$ & 21.78 & 23.03 & 19.18 & 19.32 \\
\hline & LC & 18.28 & 15.68 & 14.62 & 12.44 \\
\hline \multicolumn{6}{|l|}{$\mathrm{N}, \%$ of intake } \\
\hline \multirow[t]{2}{*}{ Fecal } & $\mathrm{HC}$ & 33.17 & 36.45 & 36.17 & 38.46 \\
\hline & LC & 36.39 & 35.78 & 40.01 & 37.05 \\
\hline \multirow[t]{2}{*}{ Urine } & $\mathrm{HC}$ & 53.18 & 36.93 & 32.45 & 47.84 \\
\hline & $\mathrm{LC}$ & 36.18 & 41.13 & 50.16 & 36.12 \\
\hline \multirow[t]{2}{*}{ Manure N } & $\mathrm{HC}$ & 87.02 & 73.52 & 68.57 & 85.67 \\
\hline & $\mathrm{LC}$ & 72.69 & 85.20 & 82.28 & 73.33 \\
\hline \multirow[t]{2}{*}{ Retained N } & $\mathrm{HC}$ & 17.28 & 31.28 & 35.71 & 19.00 \\
\hline & $\mathrm{LC}$ & 33.47 & 21.79 & 25.44 & 35.29 \\
\hline
\end{tabular}

${ }^{1}$ Cellulose $=\mathrm{ADF}-\mathrm{ADL}$.

${ }^{2}$ Hemicellulose $=\mathrm{NDF}-\mathrm{ADF}$.

and the excreted fiber amount was linearly increased as CST was increased in the diets. Starch fecal concentration was similar among dietary treatments and excretion amounts was modulated by CST as reported on the Lascano and Heinrichs (2011) companion study. These results show that as CST increase in the diets more structural and nonstructural carbohydrates were available in manure.

\section{Gas Emissions}

Table 3 presents the results for gas emissions and excretion output. Carbon dioxide emissions were higher in the $\mathrm{LC}$ treatment than in $\mathrm{HC}$. It has been reported that carbon loss through $\mathrm{CO}_{2}$ is higher in high forage diets due to greater residual $\mathrm{OM}$ in manure (Boadi et al., 2004). Although $\mathrm{CO}_{2}$ from manure is not included in GHG contribution to global warming due to its autotrophic fixation origin (Pattey et al., 2005), greater $\mathrm{CO}_{2}$ emissions from LC are concurrent with higher aerobic decomposition of $\mathrm{OM}$ when diet digestibility is lower (Lascano and Heinrichs, 2011). A tendency was observed for a linear interaction $(P=0.07) ; \mathrm{CO}_{2}$ emissions $(\mathrm{mg} / \mathrm{g})$ were reduced as CST content was increased in the $\mathrm{HC}$ treatment, whereas the opposite was true for the LC treatment. Highest average $\mathrm{CO}_{2}$ emissions were found in the LC $40 \%$ CST diet, whereas the lowest average $\mathrm{CO}_{2}$ emissions were found in the $\mathrm{HC}$ $40 \%$ CST diet.

Methane emissions from manure slurries were not different between the $2 \mathrm{~F}$ : $\mathrm{C}$ tested in this experiment. This is not in agreement with results related to diet digestibility reported in a similar digestibility study (Lascano and Heinrichs, 2011). Fresh manure releases GHG primarily in the form of $\mathrm{CH}_{4}$ when anaerobic conditions are present. Methane emissions from fresh manure have been reported to be significantly reduced $40 \mathrm{~h}$ after incubation due to its high exposure to oxygen when drying below 30\% moisture (Burford and Varani, 1976). It is important to consider that $\mathrm{CH}_{4}$ emissions in dairy cows are mostly generated by enteric fermentation and under commercial conditions manure is flushed on average 3 times per day (Sun et al., 2008b). Thus, the results reported on this experiment were to represent manure accumulation in stalls where flushing only occurs once during a 24 -h period. Lee et al. (2012) 
Table 3. Gas emissions, excretion output, and odor characteristics of dairy heifers fed differing forage to concentrate ratios (F:C) as low (LC) or high (HC) concentrate diets containing 4 levels of corn stover (CST) addition (0, 20,40, or 60\% CST in the 20 or $80 \%$ forage fraction of the diet)

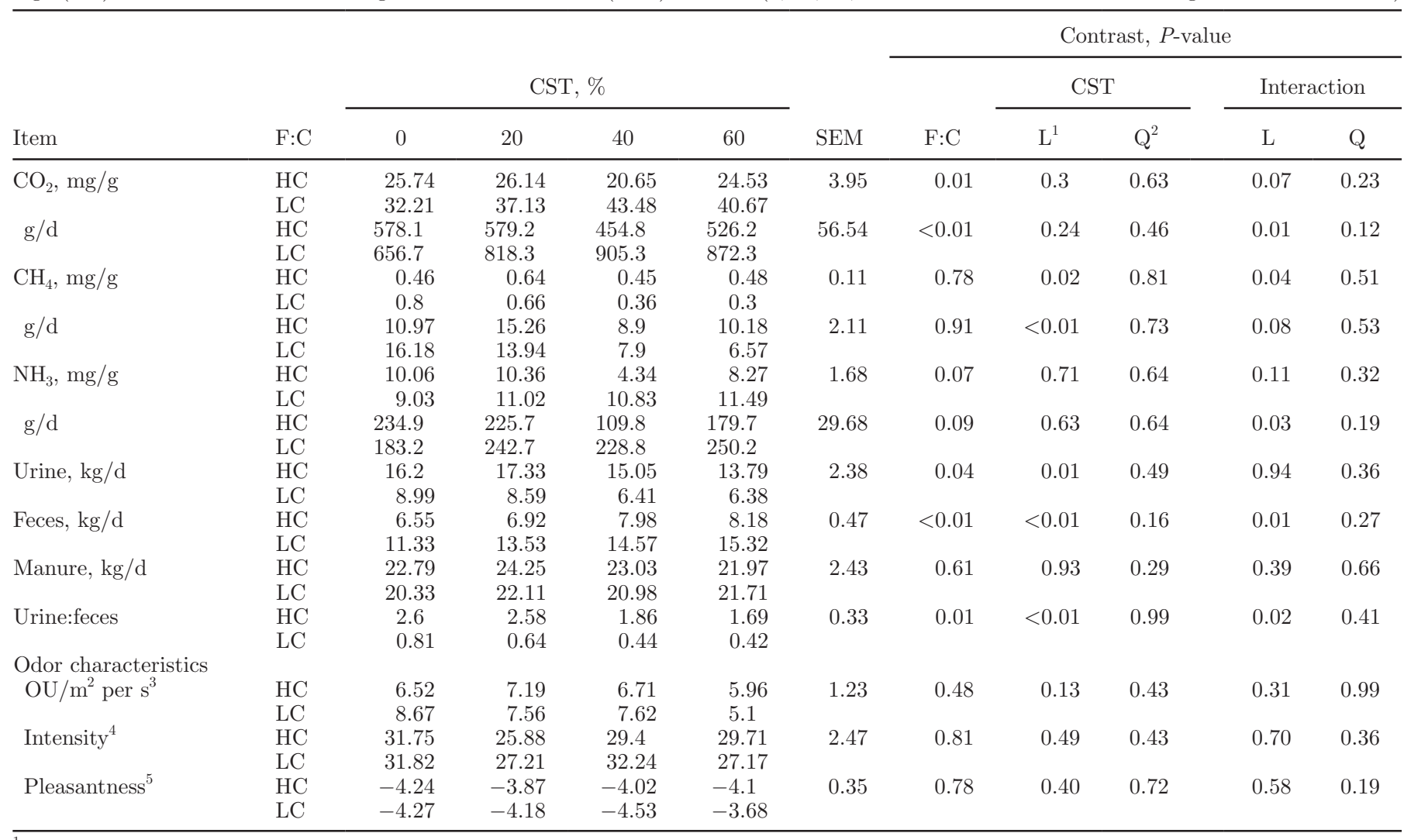

${ }^{1} \mathrm{~L}=$ linear relationship.

${ }^{2} \mathrm{Q}=$ quadratic relationship.

${ }^{3} \mathrm{OU}=$ odor unit; $1 \mathrm{OU}=123 \mu \mathrm{g}$ of n-butanol.

${ }^{4}$ Ranked on a scale of 0 to 100 .

${ }^{5}$ Ranked on a scale of -11 to +11 .

observed peak $\mathrm{CH}_{4}$ emission potential from manure using the same technique as the one described in this experiment after $21 \mathrm{~h}$ of manure from cows fed a diet with a similar CP concentration. Lodman et al. (1993), using a similar technique as the one used in the present experiment, observed higher $\mathrm{CH}_{4}$ emission rates from manure slurries of steers fed a $\mathrm{HC} \operatorname{diet}(85 \%$ of diet DM) compared with a $100 \%$ forage diet. This difference can be explained largely by the greater amount of readily fermentable substrate available in manure when animals are fed ad libitum in comparison with situations where diets are controlled to be isocaloric and isonitrogenous as in the present study; high forage diets are fed at higher intakes, whereas intakes for $\mathrm{HC}$ are reduced to maintain the previously mentioned isonutrient conditions and digestibility changes accordingly (Lascano and Heinrichs, 2011) affecting substrate availability for postexcretion anaerobic fermentation. Although NDF content in feces was higher for LC diets (Table 4), starch content was not different; thus, no dif- ferences in readily fermentable carbohydrates resulted in similar $\mathrm{CH}_{4}$ emissions. Consistent with this observation, $\mathrm{CH}_{4}$ emissions decreased linearly (Table 3 ) as fiber increased and NFC decreased in diets with CST addition. Manure stored for longer periods has been shown to increase $\mathrm{CH}_{4}$ potential emissions (Boadi et al., 2004; Aguerre et al., 2012), and emissions under long-term storage conditions need to be assessed when different dietary fiber concentrations are fed to dairy cattle.

Ammonia emissions from manure slurries were not different on a unit of manure basis between $\mathrm{HC}$ and LC diets. Lascano et al. (2008) reported higher $\mathrm{NH}_{3}$ emissions when dairy heifers were fed $\mathrm{HC}$ versus LC diets; however, LC and $\mathrm{HC}$ diets contained 25 and $35 \% \mathrm{NDF}$, respectively. In the present experiment, a numerical difference (10.06 vs. $9.03 \mathrm{mg}$ of $\mathrm{NH}_{3} / \mathrm{g}$ of manure) was found between $\mathrm{HC}$ and LC diets with no CST addition (32.85 and $35.90 \%$ NDF content). However, as dietary fiber intake and output increased (Tables 1 and 2), $\mathrm{NH}_{3}$ emissions in HC decreased linearly (Table $3 ; P=0.03$ ) 
Table 4. Fecal output of dairy heifers fed differing forage to concentrate ratios (F:C) as low (LC) or high (HC) concentrate diets containing 4 levels of corn stover (CST) addition (0,20,40, or $60 \%$ CST in the 20 or $80 \%$ forage fraction of the diet)

\begin{tabular}{|c|c|c|c|c|c|c|c|c|c|c|c|}
\hline \multirow{2}{*}{$\begin{array}{l}\text { Fecal } \\
\text { output, g }\end{array}$} & \multirow{2}{*}{ Forage } & \multirow{2}{*}{\multicolumn{4}{|c|}{ CST, \% }} & \multirow{2}{*}{ SEM } & \multicolumn{5}{|c|}{ Contrast, $P$-value } \\
\hline & & & & & & & Forage & \multicolumn{2}{|c|}{$\mathrm{CT}$} & \multicolumn{2}{|c|}{ Interaction } \\
\hline DM & $\mathrm{HC}$ & 1.31 & 1.36 & 1.62 & 1.71 & 0.03 & $<0.01$ & $<0.01$ & 0.74 & $<0.01$ & 0.27 \\
\hline $\mathrm{OM}$ & $\begin{array}{l}\mathrm{LC} \\
\mathrm{HC}\end{array}$ & $\begin{array}{l}1.81 \\
1.17\end{array}$ & 2.03 & 2.38 & 2.53 & & & & & & ( \\
\hline NDF & LC & 1.18 & 1.31 & 1.63 & 1.66 & & & & & & \\
\hline \multirow[t]{2}{*}{$\mathrm{ADF}$} & $\mathrm{HC}$ & 0.39 & 0.54 & 0.74 & 0.80 & 0.06 & $<0.01$ & $<0.01$ & 0.34 & 0.73 & 0.94 \\
\hline & LC & 0.93 & 0.99 & 1.35 & 1.33 & & & & & & \\
\hline \multirow[t]{2}{*}{ Cellulose $^{3}$} & $\mathrm{HC}$ & 0.11 & 0.17 & 0.21 & 0.28 & 0.03 & $<0.01$ & $<0.01$ & 0.63 & 0.02 & 0.54 \\
\hline & LC & 0.27 & 0.37 & 0.48 & 0.54 & & & & & & \\
\hline \multirow[t]{2}{*}{ Hemicellulose $^{4}$} & $\mathrm{HC}$ & 0.21 & 0.16 & 0.21 & 0.23 & 0.04 & 0.03 & 0.33 & 0.77 & 0.71 & 0.58 \\
\hline & LC & 0.24 & 0.32 & 0.27 & 0.33 & & & & & & \\
\hline $\mathrm{CP}$ & LC & 0.33 & 0.32 & 0.35 & 0.31 & & & & & & \\
\hline
\end{tabular}

${ }^{1} \mathrm{~L}=$ linear relationship.

${ }^{2} \mathrm{Q}=$ quadratic relationship.

${ }^{3}$ Cellulose $=\mathrm{ADF}-\mathrm{ADL}$.

${ }^{4}$ Hemicellulose $=$ NDF - ADF.

and these emissions in the LC treatment increased linearly. These results confirmed the opposite effects observed in $\mathrm{N}$ retention in a companion study (Lascano and Heinrichs, 2011) when isocaloric and isonitrogenous diets were fed to dairy heifers. Because $\mathrm{N}$ intake was not different among treatments (Table 1), this linear interaction is a result of an increase in urea excreted in urine and hydrolyzed by urease from feces (Misselbrook et al., 2005), which suggests that as CST increased in the $\mathrm{HC}$ diet, urea excreted in urine was reduced and the opposite occurred in LC diets, explaining the effects observed for $\mathrm{N}$ retention and microbial protein synthesis (Lascano and Heinrichs, 2011).

Nitrous oxide gas emissions hovered around $0.003 \mathrm{mg}$ of $\mathrm{N}_{2} \mathrm{O} \mathrm{\textrm {cm } ^ { 2 }} / \mathrm{d}$ (data not shown) with some concentrations above minimum detectable levels for the photoacoustic gas analyzer and some below (instrument noise), resulting in some $\mathrm{N}_{2} \mathrm{O}$ emissions reported below $0 \mathrm{mg}$ of $\mathrm{N}_{2} \mathrm{O} \mathrm{cm} / \mathrm{d}$. This is consistent with results reported for manure from dairy cattle having almost undetectable emissions up to 2 wk of storage (Aguerre et al., 2012; Lee et al., 2012).

Urine output was greater for $\mathrm{HC}$ diets, whereas fecal output was greater in LC. This resulted in similar manure output (Table 3). Water balance between fecal and urine output has been attributed to diet NDF concentration as a modulator (Lascano and Heinrichs, 2011). This is consistent with the results observed, as increasing CST in both $\mathrm{F}$ :C treatments resulted in a linear decrease in urine output and linear increase in fecal water. This corroborates that increasing NDF content shifts water excretion from urine toward feces (Lascano and Heinrichs, 2011). This water shift affected U:F $(P<0.01)$, resulting from reduced fecal excretion by heifers consuming the $\mathrm{HC}$ diet and the lower CST contents. This is consistent with results observed in experiments where NDF levels in diets have been manipulated (Lascano et al., 2008; Lascano and Heinrichs, 2011). The numerically higher total manure excretion by the $\mathrm{HC}$ group is explained by higher urine excretion compared with the LC group $(P=0.04)$. Urine production decreased linearly as NDF content increased with the addition of CST in the $\operatorname{diet}(P=$ 0.01). Inversely, as NDF content was reduced urine production increased. The difference in $\mathrm{U}: \mathrm{F}$ was mainly due to urine output with respect to the different CST increments in the diet. Despite the amount of feces being significantly reduced in the HC group, 2.84 times more urine was produced by this group. In contrast, the LC group produced approximately 2 times the amount of feces compared with the HC group. This is similar to results from other experiments (Zanton and Heinrichs, 2007; Lascano et al., 2008) where urine excretion was increased using a $\mathrm{HC}$ diet. It is likely that differences in $\mathrm{U}: \mathrm{F}$ in the manure under $\mathrm{HC}$ and $\mathrm{LC}$ diets affected gas emissions from fresh manure as discussed previously in 
Table 5. Correlation matrix of gas emissions and odor characteristics of manure from dairy heifers fed differing forage to concentrate ratios (F:C) as low (LC) or high (HC) concentrate diets containing 4 levels of corn stover (CST) addition $(0,20,40$, or $60 \%$ CST in the 20 or $80 \%$ forage fraction of the diet)

\begin{tabular}{|c|c|c|c|c|c|c|}
\hline Item & $\mathrm{NH}_{3}$ & $\mathrm{CH}_{4}$ & $\mathrm{CO}_{2}$ & $\mathrm{~N}_{2} \mathrm{O}$ & Odor & Intensity \\
\hline $\mathrm{NH}_{3}, \mathrm{mg} / \mathrm{kg}$ manure per $\mathrm{d}$ & - & & & & & \\
\hline $\mathrm{CH}_{4}, \mathrm{mg} / \mathrm{kg}$ manure per $\mathrm{d}$ & 0.11 & - & & & & \\
\hline$P$-value & 0.55 & & & & & \\
\hline $\mathrm{CO}_{2}, \mathrm{mg} / \mathrm{kg}$ manure per $\mathrm{d}$ & 0.61 & -0.07 & - & & & \\
\hline$P$-value & 0.01 & 0.70 & & & & \\
\hline $\mathrm{N}_{2} \mathrm{O}, \mathrm{mg} / \mathrm{kg}$ manure per $\mathrm{d}$ & -0.86 & -0.07 & -0.47 & - & & \\
\hline$P$-value & $<0.01$ & 0.70 & 0.01 & & & \\
\hline Odor, ${ }^{1} \mathrm{OU} / \mathrm{m}^{2}$ per s & 0.22 & 0.65 & 0.18 & 0.03 & - & \\
\hline$P$-value & 0.23 & $<0.01$ & 0.34 & 0.87 & & \\
\hline Intensity $^{3}$ & 0.03 & -0.17 & 0.05 & 0.16 & 0.27 & - \\
\hline$P$-value & 0.89 & 0.37 & 0.78 & 0.40 & 0.14 & \\
\hline Pleasantness $^{3}$ & -0.21 & 0.11 & -0.08 & 0.15 & -0.10 & -0.70 \\
\hline$P$-value & 0.26 & 0.54 & 0.67 & 0.43 & 0.60 & $<0.01$ \\
\hline
\end{tabular}

the parallel publication (Lascano and Heinrichs, 2011). A 50:50 U:F in dairy manure resulted in the greatest $\mathrm{NH}_{3}$ production throughout ratios ranging from 20:80 to 80:20 (Wheeler et al., 2011), suggesting a balance between available urease and urea. Differences in fecal content in fresh manure may have yielded the effects reported for $\mathrm{CO}_{2}, \mathrm{CH}_{4}$, and odor emissions due to the presence of greater carbon substrate as compared with low fecal volume.

\section{Olfactometry Results}

Olfactometry results are presented in Table 3. Odor emission rates ranged from 6.52 (HC 0\% CST) to 8.67 (LC $0 \%$ CST) OU m² $/ \mathrm{s}$ across dietary treatments. These odor values are higher than odor emission rates in beef cattle feed yards reported by Parker et al. (2005). The high magnitude of odor emissions reported in our study could be due to different feeds and animal types and sampling techniques. In the present study the source of odor was collected within a few centimeters of the manure surface and the odor was concentrated in the headspace of an enclosed chamber equipped with a continuous supply of $2 \mathrm{~L} / \mathrm{min}$ of sweep air (half of the chamber volume per min). This ventilation rate was used to mimic dairy freestall conditions during mild weather ventilation and probably does not represent airflow conditions found in the beef cattle study. Using a scale of 0 to 100, the strength of odor intensity emitted by manure was similar for all diets tested and ranged from 25.88 to 32.24 . Mean odor intensity of the manure measured by odor assessors was approximately 29, suggesting odor strength was easily recognizable (Table $3)$. From a scale of -11 to +11 , average hedonic tone was consistently -4 , with this negative value describing manure from all diets as unpleasant. Odor intensity was highly and negatively correlated with pleasantness $(P<$ $0.01, \mathrm{r}=-0.70$; Table 5 ), indicating that odor became more unpleasant as intensity increased. In contrast to other reported studies (Zahn et al., 2001; Parker et al., 2005 ), odor emission rates were not correlated with odor intensity and hedonic tone.

A positive correlation between odor emission and $\mathrm{CH}_{4}$ emissions was observed (Table 5). This indicates that other gases might be contributing to these nuisance odors being produced simultaneously with $\mathrm{CH}_{4}$, which is an odorless gas (Le et al., 2005). The main compounds contributing to nuisance odors are related to carbohydrate and $\mathrm{N}$ decomposition in manure. In the present experiment no differences in OU were found between F:C or NDF content of the diets, although it has been suggested that VFA from fermentable carbohydrates can have an effect on VOC, and thus odor, in beef cattle (Miller and Varel, 2001). Results from this experiment suggest that when diets are isocaloric, F:C, NDF content, or starch content does not influence OU during the first $2 \mathrm{~h}$ after manure accumulation. Odor release potential is at its greatest within the first $2 \mathrm{~h}$ after manure land application decreasing thereafter with time (Brandt et al., 2011). Zhu et al. (1999) reported that the most pungent odors are released from protein decomposition in swine manure; isonitrogenous diets resulting in similar $\mathrm{N}$ digestibility coefficients (Lascano and Heinrichs, 2011) in the current experiment yielded no differences relative to fecal protein content (Table 2) or odor (Table 3). This suggests that emissions of odor and $\mathrm{CH}_{4}$ from manure were likely produced by similar bacterial communities under similar environmental conditions yielding VOC responsible for creation of malodorous gas emissions. A positive correlation was found 
between $\mathrm{CO}_{2}$ and $\mathrm{NH}_{3}$ emissions $(P<0.01, \mathrm{r}=0.61$; Table 5). It is likely that both $\mathrm{CO}_{2}$ and $\mathrm{NH}_{3}$ emissions from fresh manure were produced during microbial degradation of urea and affected by similar environmental variables. No relationship was found between $\mathrm{NH}_{3}$ and odor emissions, suggesting that other odorant gases, such as volatile organic acids, hydrogen sulfide, phenol, or indole, may be affecting odor concentration in the chamber headspace (O’Neill and Phillips, 1992).

\section{CONCLUSIONS}

Responses from this experiment do not support our hypothesis that increasing NDF levels through CST would increase GHG and odor emissions in fresh manure of precision-fed dairy heifers. Other than increased $\mathrm{CO}_{2}$ emission, which is not considered in anthropogenic GHG contributions to the environment, no effect of $\mathrm{F}$ : $\mathrm{C}$ was observed in the variables measured. When comparing these parameters, our results suggest that $F: C$ does not affect GHG and odor emissions, whereas NDF levels modulate these responses. Increasing dietary fiber through inclusion of CST decreased $\mathrm{CH}_{4}$ emissions linearly and modulated $\mathrm{NH}_{3}$ emissions differently in dairy heifers fed varying $\mathrm{F}$ :C diets. Odor emissions were not influenced by $\mathrm{F}: \mathrm{C}$ and CST, but a correlation with $\mathrm{CH}_{4}$ emissions was found. Further research is needed to characterize VOC responsible for odor emissions. These results might have been affected by U:F because substrate availability and water balance in manure was shifted toward feces from urine as dietary fiber linearly increased in the diets. Odor characteristics, manure composition, $\mathrm{NH}_{3}$, and GHG from manure of precisionfed dairy heifers were successfully measured but do not account for environmental factors and longer storage conditions often present in commercial farms. Further research under these conditions is needed to assess the effect of differing dietary fiber concentrations fed to dairy cattle on gas emissions and olfactometry.

\section{REFERENCES}

Aguerre, M. J., M. A. Wattiaux, and J. M. Powell. 2012. Emissions of ammonia, nitrous oxide, methane, and carbon dioxide during storage of dairy cow manure as affected by dietary forage-to-concentrate ratio and crust formation. J. Dairy Sci. 95:7409-7416.

AOAC. 1990. Official Methods of Analysis. 15th ed. Assoc. Off. Anal. Chem., Arlington, VA.

Boadi, D. A., K. M. Wittenberg, S. L. Scott, D. Burton, K. Buckley, J. A. Small, and K. H. Ominski. 2004. Effect of low and high forage diet on enteric and manure pack greenhouse gas emissions from a feedlot. Can. J. Anim. Sci. 84:445-453.

Bouwman, A. F., D. S. Lee, W. A. H. Asman, and F. J. Dentener. 1997. A global high-resolution emission inventory for ammonia. Global Biogeochem. Cycles 11:561-587.

Brandt, R. C., H. A. Elliott, M. A. A. Adviento-Borbe, E. F. Wheeler, P. J. A. Kleinman, and D. B. Beegle. 2011. Field olfactometry as- sessment of dairy manure land application methods. J. Environ. Qual. 40:431-437.

Burford, J. L., and F. T. Varani. 1976. Energy potential through bioconversion of agricultural wastes. Final Report to the Four Corners Regional commission by Biogas of Colorado Inc. and the Colorado Energy Research Institute.

CEN. 2003. Committee for European Normalization. Air Quality-Determination of odour concentration by dynamic olfactometry. EN 13725:2003, Brussels, Belgium.

Green, B., P. Dalton, B. Cowart, G. Shaver, K. Rankin, and J. Higgins. 1996. Evaluating the "Labeled Magnitude Scale" for measuring sensations of taste and smell. Chem. Senses 21:323-334.

James, T., D. Meyer, E. Esparza, E. J. DePeters, and H. Perez-Monti. 1999. Effects of dietary nitrogen manipulation on ammonia volatilization from manure of Holstein heifers. J. Dairy Sci. 82:24302439

Laor, Y., J. A. Koziel, L. Cai, and U. Ravid. 2008. Chemical-sensory characterization of dairy manure odor using headspace solid-phase microextraction and multidimensional gas chromatography mass spectrometry-olfactometry. J. Air Waste Manag. Assoc. 58:11871197

Lascano, G. J., and A. J. Heinrichs. 2011. Effects of feeding different levels of dietary fiber through the addition of corn stover on nutrient utilization of dairy heifer precision-fed high and low concentrate diets. J. Dairy Sci. 94:3025-3036.

Lascano, G. J., G. I. Zanton, A. J. Heinrichs, and W. P. Weiss. 2010 Technical Note: A non-invasive urine collection device for female cattle: Modification of the urine cup collection method. J. Dairy Sci. 93:2691-2694.

Lascano, G. J., G. I. Zanton, M. L. Moody, P. A. Topper, E. F. Wheeler, and A. J. Heinrichs. 2008. Short communication: Effect of changing the ratio of forage to concentrate on ammonia emissions by dairy heifers. J. Dairy Sci. 91:4301-4306.

Le, P. D., A. J. A. Aarnink, N. W. M. Ogink, P. M. Becker, and M. W. A. Verstegen. 2005. Odour from animal production facilities: Its relationship to diet. Nutr. Res. Rev. 18:3-30.

Lee, C., A. N. Hristov, C. J. Dell, G. W. Feyereisen, J. Kaye, and D. Beegle. 2012. Effect of dietary protein concentration on ammonia and greenhouse gas emissions from dairy manure. J. Dairy Sci 95:1930-1941

Leytem, A. B., and R. S. Dungan. 2014. Livestock GRACEnet: A workgroup dedicated to evaluating and mitigating emissions from livestock production. J. Environ. Qual. 43:1101-1110.

Lodman, D. W., M. E. Branine, B. R. Carmean, P. Zimmerman, G M. Ward, and D. E. Johnson. 1993. Estimates of methane emission from manure of U.S. cattle. Chemosphere 26:189-199.

Miller, D. N., and V. H. Varel. 2001. In vitro study of the biochemical origin and production limits of odorous compounds in cattle feed lots. J. Anim. Sci. 79:2949-2956.

Misselbrook, T. H., J. M. Powell, G. A. Broderick, and J. H. Grabber. 2005. Dietary manipulation in dairy cattle: Laboratory experiments to assess the influence on ammonia emissions. J. Dairy Sci. 88:1765-1777

Mosier, A. R., J. M. Duxburry, J. R. Freney, O. Heinemeyer, K. Minami, and D. E. Johnson. 1998. Mitigating agricultural emissions of methane. Clim. Change 40:39-80.

NRC. 2001. The Nutrient Requirements of Dairy Cattle. 7th rev. ed. Natl. Acad. Press, Washington, DC

O'Neill, D. H., and V. R. Phillips. 1992. A review of the control of odour nuisance from livestock buildings. Part 3: Properties of the odorous substances which have been identified in livestock wastes or in the air around them. J. Agric. Eng. Res. 53:23-50.

Parker, D. B., M. B. Rhoades, G. L. Schuster, J. A. Koziel, and Z. L. Perschbacher. 2005. Odor characterization at open-lot beef cattle feedyards using triangular forced-choice olfactometry. Trans. Am. Soc. Agric. Eng. 48:1527-1535.

Pattey, E., M. K. Trzcinski, and R. L. Desjardins. 2005. Quantifying the reduction of greenhouse gas emissions as a result of composting dairy and beef cattle manure. Nutr. Cycl. Agroecosyst. $72: 173-187$ 
Place, S. E., and F. M. Mitloehner. 2010. Invited review: Contemporary environmental issues: A review of the dairy industry's role in climate change and air quality and the potential of mitigation through improved production efficiency. J. Dairy Sci. 93:34073416.

Sun, H., Y. Pan, Y. Zhao, W. Jackson, L. Nuckles, V. Arteaga, and F. M. Mitloehner. 2008a. Effects of sodium bisulfate on alcohol, amine, and ammonia emissions from dairy slurry. J. Environ. Qual. 37:608-614.

Sun, H., S. L. Trabue, K. Scoggin, W. A. Jackson, Y. Pan, Y. Zhao, I. L. Malkina, J. A. Koziel, and F. M. Mitloehner. 2008b. Alcohol, volatile fatty acid, phenol, and methane emissions from dairy cows and fresh manure. J. Environ. Qual. 37:615-622.

Tamminga, S. 1992. Nutrition management of dairy cows as a contribution to pollution control. J. Dairy Sci. 75:345-357.

US EPA (Environmental Protection Agency). 2014. Inventory of U.S. greenhouse gas emissions and sinks: 1990-2012. Accessed Oct. 10 2014. http://www.epa.gov/climatechange/emissions/usinventory report.html.

Weiss, W. P., L. B. Willett, N. R. St-Pierre, D. C. Borger, T. R. McKelvey, and D. J. Wyatt. 2009. Varying forage type, metabolizable protein concentration, and carbohydrate source affects manure excretion, manure ammonia, and nitrogen metabolism of dairy cows. J. Dairy Sci. 92:5607-5619.

Wheeler, E. F., P. A. Topper, R. C. Brandt, N. E. Brown, A. Adviento-Borbe, R. S. Thomas, and G. A. Varga. 2011. Multiple-chamber instrumentation development for comparing gas fluxes from biological materials. Appl. Eng. Agric. 27:1049-1060.

Zahn, J. A., A. A. DiSpirito, Y. S. Do, B. E. Brooks, E. E. Cooper, and J. L. Hatfield. 2001. Correlation of human olfactory responses to airborne concentrations of malodorous volatile organic compounds emitted from swine effluent. J. Environ. Qual. 30:624-634.

Zanton, G. I., and A. J. Heinrichs. 2007. The effects of controlled feeding of a high-forage or high-concentrate ration on heifer growth and first-lactation milk production. J. Dairy Sci. 90:3388-3396.

Zanton, G. I., and A. J. Heinrichs. 2009. Digestion and nitrogen utilization in dairy heifers limit-fed a low or high forage ration at four levels of nitrogen intake. J. Dairy Sci. 92:2078-2094.

Zhu, J., G. L. Riskowski, and M. Torremorell. 1999. Volatile fatty acids as odor indicators in swine manure-A critical review. Trans. Am. Soc. Agric. Eng. 42:175-182. 